\title{
Anti-inflammatory and antinociceptive activities of Loasa speciosa in rats and mice
}

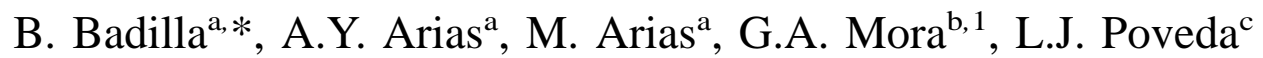 \\ anstituto de Investigación en Ciencias Farmacéuticas (INIFAR), Facultad de Farmacia, \\ Universidad de Costa Rica, San José 2060, Costa Rica \\ ${ }^{\mathrm{b}}$ Centro de Investigaciones en Productos Naturales (CIPRONA) y Facultad de Farmacia, \\ Universidad de Costa Rica, San José, Costa Rica \\ ${ }^{\mathrm{c}}$ Herbario Juvenal Valerio Rojas, Facultad de Ciencias Ambientales, Universidad Nacional, Heredia, \\ Costa Rica
}

Received 10 January 2000; accepted in revised form 14 October 2002

\begin{abstract}
In the range of doses of $250-500 \mathrm{mg} / \mathrm{kg}$ (given i.p.) the aqueous extract of Loasa speciosa leaves showed an inhibitory effect on leukocyte migration, and a reduction on the pleural exudate, as well as dose-dependent anti-inflammatory and peripheral antinociceptive activities.
\end{abstract}

(c) 2002 Elsevier Science B.V. All rights reserved.

Keywords: Loasa speciosa; Aqueous extract; Anti-inflammatory; Antinociceptive; Rat paw edema

\section{Introduction}

Loasa speciosa belongs to a family comprising 15 genera and approximately 250 species [1] and is described by Standley [2] as an erect herb of 1-1.5 m, covered with long stinging hairs. The lower leaves are opposite, palmate-lobate and the flowers are recurved, campanulate, approximately $6-\mathrm{cm}$ long with orange-yellow petals. It is popularly known as 'Campana' (bell) referring to the shape of the

\footnotetext{
*Corresponding author.

E-mail address: bbadilla@cariari.ucr.ac.cr (B. Badilla).

${ }^{1}$ E-mail: gamora@ cariari.acu.ac.cr

0367-326X/03/\$ - see front matter (C) 2002 Elsevier Science B.V. All rights reserved. PII: S 0367-326X(02)00299-X
} 
flower and 'Ortiga veinticuatro' (Nettle twenty-four), as a reference to the duration of the pain that results from stinging by the plant [1]. Standley refers to it as endemic of Costa Rica but it has been reported to be present also on the highlands (above $2000 \mathrm{~m}$ ) of Panama [3].

Information obtained from local communities indicates that an infusion of the leaves is used orally in folk medicine as anti-inflammatory and analgesic (Poveda J. L., personal communication).

In a preliminary study [4], an aqueous extract of the leaves significantly inhibited carrageenan-induced rat paw edema when administered intraperitoneally (i.p.) at $500 \mathrm{mg} / \mathrm{kg}$. The present study was, therefore, undertaken to confirm the antiinflammatory, to evaluate the antinociceptive properties of this plant extract and to propose a possible mechanism of action.

\section{Experimental}

\subsection{Plant material}

L. speciosa leaves were collected in San Gerardo de Dota (San José), in January 1995. The plant was identified at source by Professor Luis Poveda, of the Universidad Nacional (Heredia, Costa Rica) and a voucher specimen (JVR 7001) was deposited in the Herbarium of the Universidad Nacional.

\subsection{Preparation of the extract}

The leaves were chopped and dried at approximately $40{ }^{\circ} \mathrm{C}$ for 3 days. A decoction was prepared using a proportion of $10 \mathrm{~g}$ of dried leaves in $100 \mathrm{ml}$ of water by warming for $30 \mathrm{~min}$ at $70{ }^{\circ} \mathrm{C}$. The solution was filtered, concentrated and freeze-dried to obtain the crude aqueous extract (yield: 15.75\%).

\subsection{Animals}

The Animal Care Unit of Mexico Hospital of Costa Rica supplied male Winstar rats, weighing 180-220 g and the Animal Care Unit of University of Costa Rica supplied female BAL-BC mice, weighing 25-35 g. The animals had free access to food and water and were kept in standardized environmental conditions on a 12/ 12-h light/dark cycle. Before each test, the animals were fasted for at least $12 \mathrm{~h}$.

\subsection{Carrageenan-induced rat paw edema}

Acute inflammation was tested on edema induced by carrageenan in rats. Carrageenan $(0.1 \mathrm{ml}$ of a $1 \%$ solution in saline) was injected into the plantar surface of the right hind paw of the rats [5,6]. While the contralateral paw was injected with $0.1 \mathrm{ml}$ saline solution. Animals, allocated to treatment in groups of six, were injected i.p. with the test extract $(125,250$ and $500 \mathrm{mg} / \mathrm{kg}$, dissolved in saline), indomethacin $(10 \mathrm{mg} / \mathrm{kg})$ as reference drug or $0.1 \mathrm{ml}$ of $0.9 \%$ saline solution 
(control). The paw volume was measured before the injection and each hour afterwards for a period of $6 \mathrm{~h}$ with a plethismometer (Ugo Basile 7140). The difference between the left and the right paw volumes indicated the degree of inflammation. The average increase in paw volume of each group was calculated.

\subsection{Carrageenan-induced pleurisy in rats}

The test was performed according to Vinegar et al. [7]. Groups of six rats each were pretreated with the test extract $(250$ or $500 \mathrm{mg} / \mathrm{kg}$, i.p.), indomethacin (10 $\mathrm{mg} / \mathrm{kg}$, i.p. $)$ or saline $(0.1 \mathrm{ml})$. One hour later all animals received an intrapleural injection of carrageenan $(0.25 \mathrm{ml}$ of $1 \%$ solution in $0.9 \%$ saline $)$ on the right side of the thorax. Three hours later the animals were anaesthetized with ether and killed by bleeding through the portal vein. The pleural exudate was collected and the pleural cavity was washed with $1.0-\mathrm{ml}$ saline containing heparin $(10 \mathrm{IU} / \mathrm{ml})$. The number of migrating leukocytes in the exudate was determined with a Neubauer chamber. Results were expressed as mean \pm S.E.M. of exudate pleural volumes $(\mathrm{ml})$ and of total leukocytes.

\subsection{Formalin-induced nociception in mice}

The method of Hunskaar et al. [8] was used. Each group of six mice each, was treated with the test extract $(125,250$ and $500 \mathrm{mg} / \mathrm{kg}$ i.p. in saline solution), saline solution (i.p.) and indomethacin $(10 \mathrm{mg} / \mathrm{kg}$ i.p.). One hour after treatment all animals were injected with $20 \mu \mathrm{l}$ of $1 \%$ formalin in saline solution into the plantar surface of the left hind paw. Licking time was measured in the test chamber over $30 \mathrm{~min}$, in two phases: the first phase was from time zero to $5 \mathrm{~min}$ after formalin injection and the second phase was from 20 to $30 \mathrm{~min}$ after formalin injection.

\subsection{Statistical analysis}

The results are expressed as mean \pm S.E.M. The Student's $t$-test was used for comparison vs. the data of the control groups. Differences with $P<0.05$ were considered statistically significant.

\section{Results}

\subsection{Carrageenan-induced rat paw edema}

The intraplantar injection in the hind paw with carrageenan induced a progressive edema reaching a maximum after $3 \mathrm{~h}$. Animals treated intraperitoneally with aqueous extract of L. speciosa at doses of 125,250 and $500 \mathrm{mg} / \mathrm{kg}$ showed significant edema inhibition in all phases of the experiment. The anti-inflammatory effect was dose-related and comparable with that of indomethacin $10 \mathrm{mg} / \mathrm{kg}$, i.p. (Fig. 1). 


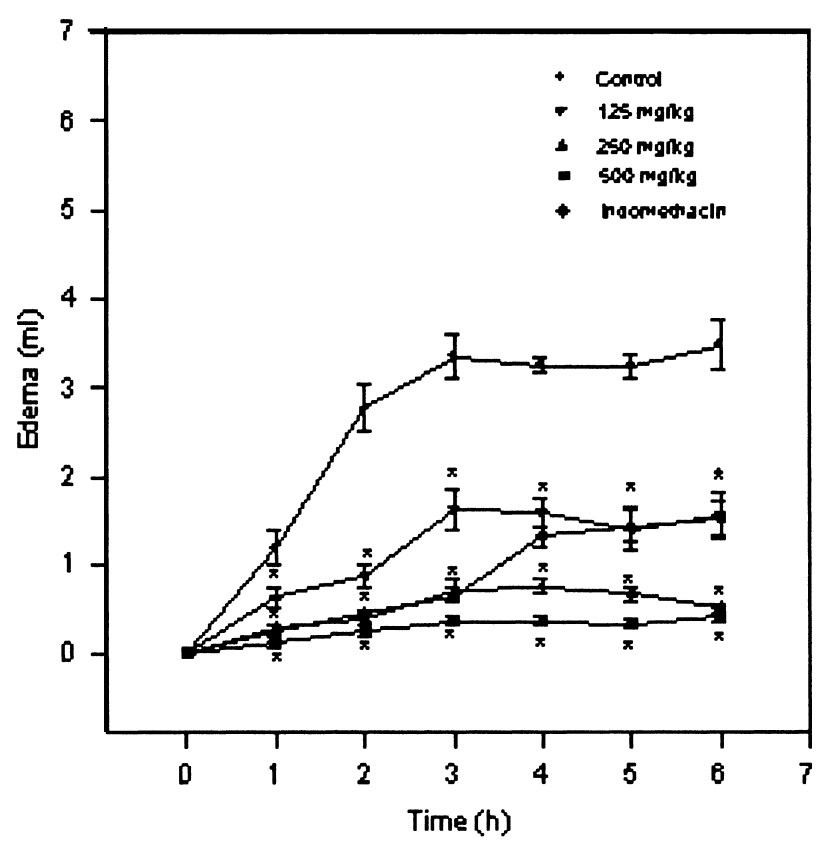

Fig. 1. Effect of the aqueous extract of Loasa speciosa leaves on carragenan-induced edema in rats. Values are mean \pm S.E.M. $(n=6) ; * P>0.05$.

\subsection{Carrageenan-induced pleurisy in rats}

The volume of the pleural exudate in the saline group was $0.32 \pm 0.02 \mathrm{ml}$ and the leukocyte count was $4.35 \pm 0.10 \times 10^{3}$ cells $/ \mathrm{ml}$. Treatment with the aqueous extract at 250 and $500 \mathrm{mg} / \mathrm{kg}$ i.p. decreased both the pleural exudate $(0.12 \pm 0.02$ $\mathrm{ml}$ and $0.10 \pm 0.01 \mathrm{ml}$, respectively), and leukocyte migration $\left[(0.52 \pm 0.02) \times 10^{3}\right.$ cells $/ \mathrm{ml}$ and $(0.45 \pm 0.03) \times 10^{3}$ cells $/ \mathrm{ml}$, respectively]. Treatment with indomethacin $(10 \mathrm{mg} / \mathrm{kg}$ i.p.) produced an exudate of $0.13 \pm 0.01 \mathrm{ml}$ and a leukocyte migration of $0.45 \pm 0.03 \times 10^{3}$ cells $/ \mathrm{ml}$. As shown by Giemsa staining, $82 \%$ of the

Table 1

Effect of the aqueous extract of Loasa speciosa leaves on carragenan-induced pleurisy in rats

\begin{tabular}{lll}
\hline Treatment & $\begin{array}{l}\text { Pleural exudate } \\
(\mathrm{ml})\end{array}$ & $\begin{array}{l}\text { Leukocytes } \\
\left(\times 10^{3} \text { cells } / \mathrm{ml}\right)\end{array}$ \\
\hline Control $(0.9 \%$ saline $)$ & $0.32 \pm 0.02$ & $4.35 \pm 0.11$ \\
L. speciosa $250 \mathrm{mg} / \mathrm{kg}$ & $0.12 \pm 0.02^{*}$ & $0.52 \pm 0.02^{*}$ \\
L. speciosa $500 \mathrm{mg} / \mathrm{kg}$ & $0.10 \pm 0.01^{*}$ & $0.45 \pm 0.03^{*}$ \\
Indomethacine & $0.13 \pm 0.01^{*}$ & $0.45 \pm 0.03^{*}$ \\
\hline
\end{tabular}

Columns represent the mean values \pm S.E.M. $(n=6) ; * P<0.05$. 


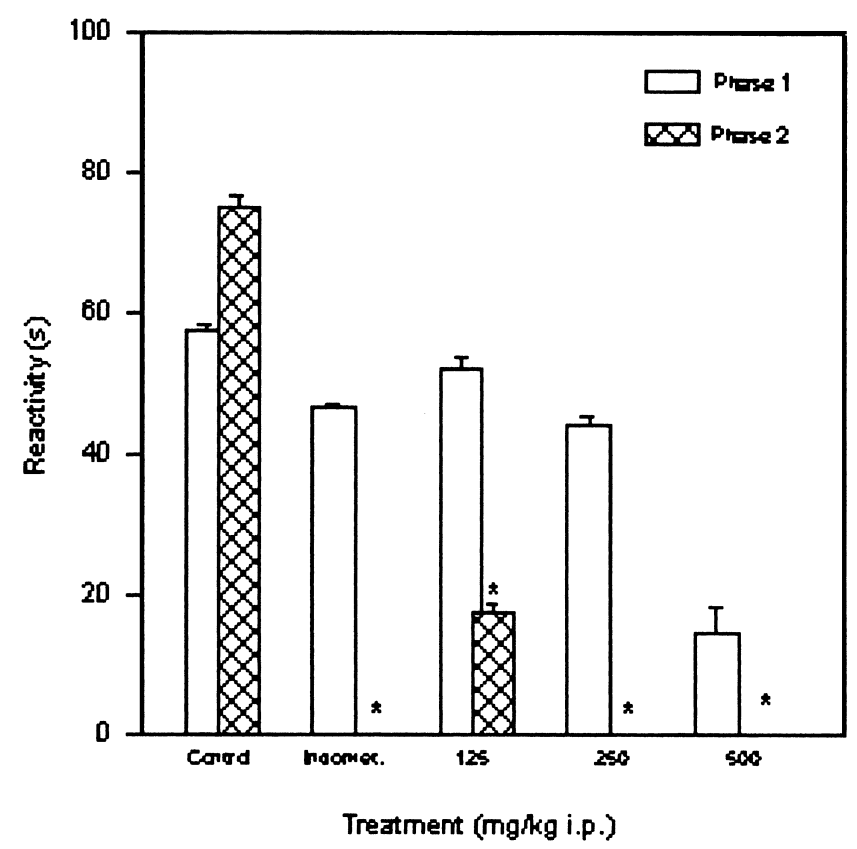

Fig. 2. Effect of the aqueous extract of Loasa speciosa leaves on formalin-induced nociception in mice. Bars represent the mean values \pm S.E.M. $(n=6) ; * P<0.05$.

cells were polymorphonuclear neutrofils, $19 \%$ monocytes, $7 \%$ little lymphocytes and $2 \%$ eosinofils (Table 1 ).

\subsection{Formalin-induced nociception in mice}

Animals treated with saline showed response times of $57.36 \pm 1.13 \mathrm{~s}$ and $75.15 \pm 1.52 \mathrm{~s}$ in the first and second phases, respectively. Animals treated with indomethacin $(10 \mathrm{mg} / \mathrm{kg}$ i.p. $)$ showed only the first phase $(46.57 \pm 0.61 \mathrm{~s})$; the second phase was totally inhibited. Those treated with the extract $(125 \mathrm{mg} / \mathrm{kg}$ i.p. $)$ showed both phases $(52.27 \pm 1.33 \mathrm{~s}$ and $17.58 \pm 1.31 \mathrm{~s}$, respectively), but animals treated with 250 and $500 \mathrm{mg} / \mathrm{kg}$ i.p. showed only the first phase $(43.98 \pm 1.46 \mathrm{~s}$ and $14.73 \pm 3.63 \mathrm{~s}$, respectively) (Fig. 2).

\section{Discussion and conclusions}

The most widely used primary test for the screening of new anti-inflammatory agents is the carragenan-induced edema in the rat hind paw [5]. This edema depends on the participation of kinins and polymorphonuclear leukocytes with their proinflammatory factors, including prostaglandins [9]. The development of edema in the paw of the rat, after the injection of carragenan, has been described by Vinegar et al. [10] as a biphasic event. The initial phase, observed during the first hour, is 
attributed to the release of histamine and serotonin [11]; the second one is due to the release of prostaglandin-like substances [10]. It has been reported that the second phase of edema is sensitive to both steroidal and non-steroidal anti-inflammatory agents [6]. Based on this, it could be argued that the significant activity observed in the suppression of the first phase of carrageenan-induced inflammation may be due to inhibition of the release of early mediators, such as histamine and serotonin, and the action on the second phase may be explained by an inhibition of cyclooxygenase (Fig. 1).

The tests performed with the aqueous extract of $L$. speciosa leaves in the pleurisy model showed that this extract behaves as an inhibitor of leukocyte migration and the formation of pleural exudate when given intraperitoneally, as some non-steroidal anti-inflammatory drugs do [12].

In the formalin test, there is a distinct biphasic response and analgesic drugs act differently in its early and late phases. So, this test can also be used to elucidate the mechanisms of pain and analgesia [13]. L. speciosa extract is endowed with peripheral analgesic activity, possibly related to an inhibition of cyclooxygenase. According to Seibert et al. [14], it may be inferred that the extract inhibits cyclooxygenase-2, while the available data do not allow to assume that $L$. speciosa also inhibits cyclooxygenase- 1 .

The results of the present study show that the aqueous extract of leaves of $L$. speciosa, when given intraperitoneally, has analgesic and anti-inflammatory activities, which are dose-dependant over a range of $125-500 \mathrm{mg} / \mathrm{kg}$. Further studies are necessary to assess the potential clinical use of this plant, or its extract or active principles, as anti-inflammatories and/or analgesics. Work to determine its possible immunomodulatory activity is under way.

\section{Acknowledgments}

This study was carried out with financial support from Vicerrectoría de Investigación (Universidad de Costa Rica) N 410-95-561, and Instituto de Investigaciones Farmacéuticas (INIFAR) Facultad de Farmacia, Universidad de Costa Rica. We would like to acknowledge the collaboration of NAPRALERT and CYTED.

\section{References}

[1] Montiel L. 2nd ed. Introducción a la flora de Costa Rica. Costa Rica: Universidad de Costa Rica, 1991. p. 248.

[2] Standley PC. Chicago, USA: Field Museum of Natural History, 1937. p. 736.

[3] Missouri Botanical Garden, W3TROPICOS Data Base: http://mobot.mobot.org/W3T/Search/ vast.html.

[4] Badilla B, Mora G, Poveda LJ. Rev Biol Trop 1999;47:723.

[5] Winter CA, Risley EA, Nuss GW. Proc Soc Exp Biol Med 1962;111:544.

[6] Di Rosa M, Giroud PJ, Willoughby DA. J Pathol 1971;101:15.

[7] Vinegar R, Truax JF, Selph JL. Fed Proc 1982;41:2588.

[8] Hunskaar S, Berge OB, Hole K. Pain 1986;25:125.

[9] Damas J, Remacle-Volon G, Deflandre B. Arch Pharmacol 1986;332:196. 
[10] Vinegar R, Schreiber EJ. Pharmacol Exp Ther 1969;166:96.

[11] Crunkhon P, Meacock SER. Br J Pharmacol 1971;42:392.

[12] Mikami T, Miyasaka K. Eur J Pharmacol 1983;95:1.

[13] Tjolsen A, Berge OG, Hunskaar S, Rosland JH, Hole K. Pain 1992;51:5.

[14] Seibert K, Zhang Y, Leahy K, Hauser S, Masferrer J, Perkins W, et al. Proc Nat Acad Sci 1994;91:12013. 